\author{
International \\ Journal of \\ ofducation \\ DOI : 10.15740/HAS/IJPE/8.2/98-100 \\ e ISSN-0976-7924 $\mathbf{\square}$ Visit us : www.researchjournal.co.in \\ A Case Study \\ Volume 8 | Issue 2 | October, 2015 | 98-100
}

\title{
Need and importance of mental health education
}

\section{SAHADEV MAAN}

Received : 16.09.2015; Accepted : 30.09.2015

Author for correspondence

SAHADEV MAAN

Department of Physical Education and Sports, C.C.R. P.G. College, MUZAFFARNAGAR (U.P.) INDIA

\section{ABSTRACT}

The purpose of the study was to find out the need and importance of mental health education for a good teacher, coach, trainer and psychologist. From this study we can conclude that need and importance of mental health education is very important for a good teacher, coach, trainer and psychologist. It is important on the part of teachers worked on the special attention on abnormal and dull students, too recognize individual differences of the students, finding out mental health problems of students, solving mental health problems of students, good understanding a women students, teachers and other person, for emotional maturity, for making the atmoshphere of class and college interesting, high standard mental health of a teacher, good attitude of teacher, giving best teaching, coaching and training, for promotion of mental health of society etc.

- KEY WORDS : Need, Mental health education

- HOW TO CITE THIS PAPER : Maan, Sahadev (2015). Need and importance of mental health education. Internat. J. Phy. Edu., 8 (2) : 98-100. 